\title{
Sir Charles Bright, Kt., M.I.C.E., M.I.E.E.
}

Sir Charles Bright, who died on November 20, 1937, was born in I863. The son of the man who laid the first Atlantic cable naturally devoted himself to submarine cable work and for some fifteen or more years this claimed his energies, many cables under the oceans being laid or organised by him. But in the invention of wireless telegraphy he recognised the dawn of a new era, and in the early years of the century he became associated with wireless and its application to shipping. He successfully advocated wireless stations round the coast and extended his activities to world radio as the possibilities of the subject developed. His interest in aeronautics led him to apply wireless to ships of the air, as earlier to ships of the sea, and the association with many parts of the Empire through his cable and radio work brought him to other aspects of imperial development, especially trade, industries and patent rights.

With his wide knowledge of other countries he supported the League of Nations, of which he was a Vice-President, and other movements towards peace and amity, and as a keen participator in open-air games and exercise he helped in the promotion of playing fields and athletic clubs. Both his work as a cable engineer and his interest in the Empire made him an extensive traveller, and his experience made him a valuable member of many Government Commissions, including Imperial Relations, Radio-telegraphy, the Dominions, the Royal Flying Corps and Air Congress. These subjects and histories of his father Sir Charles Tilston Bright and of the first Atlantic cable, with contributions to the Encyclopadia Britannica and the more important periodicals and technical journals, occupied his pen.

A man of kindly personality, he made many friends. His life was full, fruitful and interesting: such men are the mainstay of their generation.

He was elected a Fellow of this Society in 1895.

F. G. B. 